\title{
Corporate Social Responsibility and Credit Ratings: On the Moderating Role of Firm Capability
}

\author{
Chu-Hsiung Lin ${ }^{1}$, Tzu-Chuan Kao ${ }^{2}$, Chang-Cheng Changchien ${ }^{3}$ and Chien-Hui Wu ${ }^{4}$
}

\begin{abstract}
This study reexamines the effects of corporate social responsibility (CSR) on credit ratings. On examining a sample of listed firms in Taiwan from 2013 to 2015, we find that our results do not support that CSR activities can enjoy more favorable credit ratings. However, firm capabilities can improve credit ratings, and the relationship between CSR and credit ratings is significant for firms with high capability. Our results indicate that CSR activities are beneficial to credit ratings only for firms with high capabilities.
\end{abstract}

JEL classification numbers: G30, G32

Keywords: Corporate Social Responsibility, Credit Ratings, Firm Capability, Corporate Financial Performance.

\section{Introduction}

Many studies suggest that corporate social responsibility (CSR) is negatively associated with default risk ( Hsu and Liu, 2017; Shahrour et al., 2021) and reveals that firms with inferior CSR performance exhibited a higher default risk. Vassalou and Xing (2004) and Bakshi et al. (2006) show that an important mechanism that links CSR with default risk is that CSR improves a firm's financial performance, and further reducing default risks. Sun and Cui (2014) examine the influences of the endowment differences within firms and the uncertainty of external environments on the relationship between CSR and default risk, and the results verify that companies' engagement in CSR is conducive to reducing their default risk. Furthermore, CSR has a strong effect on default risk reduction in high dynamism environments. Those results demonstrate that firms with good CSR performance have low default risk.

Credit rating agencies are important financial intermediaries in capital market. They evaluate default risk and recovery rate of debt issuers and publish ratings to indicate their opinions about issuers' willingness and capacity to service debt. Firms with superior credit ratings have better access to financial markets and can borrow at a lower cost. Favorable credit ratings also inspire investor confidence. The literature on credit ratings documents a large number of firm characteristics that influence them. However, the role of nonfinancial attributes (such as CSR) is rarely examined in the literature.

Attig et al. (2013) argue that CSR reduces the perceived risk of financial distress, and thus investment in CSR is associated with higher credit ratings. Jiraporn et al. (2014) find that more socially responsible firms enjoy more favorable credit ratings. These results show that credit rating agencies tend to award

\footnotetext{
1 National Kaohsiung University of Science and Technology, Taiwan

2 Kun Shan University, Taiwan

3 Chang Jung Christian University, Taiwan

${ }^{4}$ National Penghu University of Science and Technology, Taiwan
} 
relatively high ratings to firms with good CSR performance.

According to the resource-based theory and dynamic capability theory, firm capability is a firm's inherent competency in managing its internal factors (Teece et al., 1997). It is a competitive strength that integrates internal and external organizational resources to adapt to changing circumstances. A firm with high capability can effectively allocate resources, assets, and activities (Teece et al., 1997) to reduce the possibility of imitation and competition (Krasnikov \& Jayachandran, 2008).

Luo and Bhattacharya (2006) indicate that firm capabilities facilitate CSR's function and, therefore, strengthen the relationship between CSR and default risk reduction. The results show that firms with higher capabilities engage in CSR activities, tend to have lower default risk, and, thus, have higher credit ratings.

The study extends the above line of research by examining whether the strength of the relationship between CSR and credit ratings varies when firms differ in their capabilities. We formulate the moderating effects between CSR and firm capability and describe a more complete pattern of CSR functions under different internal conditions, thus improving the understanding of CSR benefits.

To test the hypothesis that firm capability will moderate the relationship between CSR and credit ratings, we use Taiwanese listed firms on the Taiwan Stock Exchange (TSE) from 2013 to 2015. The empirical results show that CSR does not appear to have a significant effect on credit ratings, inconsistent with previous findings (i.e., Attig et al., 2013; Jiraporn et al., 2014). However, we find that firm capabilities can improve credit ratings and that the relationship between CSR and credit ratings is significant for firms with high capability. Our robustness check receives the same results. Our results do not support that CSR activities can increase a firm's credit rating - this relationship is significant only for firms with high capability. Our evidence is consistent with the findings that CSR activities will generate insurance-like assets for high-capability firms to explore their market (Luo and Bhattacharya, 2006; Krasnikov and Jayachandran, 2008). This study complements related literature by investigating the role of firm capability in the relationship between CSR and credit ratings.

\section{Method and Data}

\subsection{The Model}

We employ the ordered logistic regression model with industry and year fixed effects to test the hypothesis. Following the literature (Sun and Cui, 2014; Attig et al., 2013), we control for several factors that have been shown to affect default risk or credit ratings. The control variables include environmental dynamics $(D Y)^{5}$, environmental complexity $(C M)^{6}$, earnings management $(M D)^{7}$, financial leverage $(L E V)$, cumulative return (CUMRET), stock turnover rate $(T V)$, return on assets $(R O A)$, firm size (LNSIZE), firm age ( $L N A G E)$, cash flow volatility $(C F V)$, cash flow growth rate $(C F G)$, the industry dummy variables for 18 industries (DUMMY_IND), and the yearly dummy variables for three years (DUMMY_YEAR).

We focus on the coefficient of $C S R \times C A P$, which captures the moderating effect of firm capability on the relationship between CSR and credit ratings:

\footnotetext{
${ }^{5}$ This study employs a five-year moving windows time-series model and uses industrial operating income for a regression estimation of time. The antilog of the standard error of the coefficient represents the volatility of sales and as the measure of environmental dynamism.

${ }^{6}$ According to the methods proposed by Keats and Hitt (1988) as well as by Sun and Cui (2014), this study assesses environmental complexity by using the Herfindahl-Hirschman index (HHI) to examine the distribution and competition of the sample companies in each industry and the 1-HHI to measure environmental complexity within each industry.

7 This study uses managerial discretion power in information disclosure as a proxy variable for earnings management, which estimated by a Modified-Jones model (Kothari et al., 2005).
} 


$$
\begin{aligned}
& \operatorname{RATING}_{i, t}=\beta_{0}+\beta_{1} \operatorname{CSR}_{i, t}+\beta_{2} C A P_{i, t}+\beta_{3} \operatorname{CSR}_{i, t} \times C A P_{i, t}+\beta_{4} D Y_{i, t}+\beta_{5} C M_{i, t}+\beta_{6} M D_{i, t}+\beta_{7} L E V_{i, t} \\
& +\beta_{8} \operatorname{CUMRET}_{i, t}+\beta_{9} T_{i, t}+\beta_{10} \text { ROA }_{i, t}+\beta_{11} L_{N S I Z E_{i, t}}+\beta_{12} L N A G E_{i, t}+\beta_{13} C_{F} V_{i, t} \\
& +\beta_{14} C F G_{i, t}+\sum_{j=1}^{K} \gamma_{j} \times D U M M Y_{-} I N D_{j}+\sum_{i=1}^{T} \delta_{l} \times D U M M Y_{-} Y E A R_{\iota}+\varepsilon_{i, t}
\end{aligned}
$$

where $i$ represents firm $i d, t$ is year, and $j$ is the industry sector.

RATING denotes the firm credit ratings measured by the Taiwan Corporate Credit Risk Index (TCRI) from the Taiwan Economic Journal. TCRI ranks the credit quality of each firm from 1 to 9. Firms with ratings ranging from 1 to 4 are considered the lowest risk, equivalent to the Standard \& Poor investment grade ratings. Firms with ratings from 5 to 6 are considered to be moderate risk. Firms with ratings from 7 to 9 are considered the highest risk; these are often referred to as speculative grade ratings. Firms in financial crisis are rated 10.

Following Kim et al. (2014), our CSR measure is an aggregate CSR score (CSR_TOTAL) that captures firm-level social responsibility engagement based on four qualitative areas of strength from the Corporate Social Responsibility Best Practice Principles (hereafter "Principles") proposed by the TSE. The Principles consist of 24 articles and 38 items across four dimensions, including the implementation of corporate governance $C S R_{-} G V$ ), development of sustainable environments (CSR_SE), maintenance of public welfare (CSR_SC), and enhancement of CSR disclosures (CSR_ID). We then follow Kim et al. 's (2014) method to check if each firm had met any of the 38 items across the four dimensions. A firm is assigned a score of 1 if it meets a criterion and 0 otherwise. The maximum score is 38 points, of which $C S R_{-} G V, C S R_{-} S E, C S R_{-} S C$, and $C S R_{-} I D$ account for $9,10,11$, and 8 points, respectively. We also calculate the CSR net counts $\left(C S R_{-} N E G\right)$ as the total CSR score minus total concerns. CSR scores are standardized to mitigate year or industry effects when we conduct equation estimation.

Furthermore, Ayabakan et al. (2017) point out that the term "firm capability" lacks a unified and formal definition and assessment method. They suggest that a firm's capability, compared with its competitors, should be assessed through the firm's relative capability of transforming similar input resources into outputs (Santhanam and Hartono, 2003). Thus, we refer to the recommendations of Ayabakan et al. (2017) and employ data envelopment analysis (DEA) to assess a firm's relative capability by considering the balance between inputs and outputs. The efficiency derived from DEA is in the form of technical efficiency, which considers the product of pure efficiency and scale efficiency. The economic implications are in accordance with the statements of the resource-based and the dynamic capability theories: that is, firm capability refers to a firm's capability in terms of integrating its tangible, intangible, and organizational resources. We refer to Assaf and Magnini (2012) and adopt the total costs and operating costs as input variables, while net operating income served as the output variable.

\subsection{Data}

The data were obtained from the Taiwan Economic Journal (TEJ). The dataset contains 687 Taiwanese listed firms in TSE from 18 industries, covering a period from 2013 to 2015. Our samples exclude industries such as finance, securities, investments, and missing data.

\section{Empirical results}

\subsection{Descriptive statistics}

Table 1 presents descriptive statistics for all empirical variables over the sample period, calculated on the basis of yearly data. The mean credit rating (5.4202) exceeds the median (5), which indicates that the firms listed in TSE are at a moderate default risk, and approximately 50\% of the sample firms exhibit a default risk of more than 5. The mean total CSR score (CSR_TOTAL) is 21.5177. This implies that firms 
listed in TSE require much improvement in CSR involvement. The maximum, minimum, and standard deviation of CSR_TOTAL are 35, 8, and 5.178, respectively. It shows a large discrepancy among the degrees of CSR involvement. The mean total score excluding negative events (CSR_NEG) is 21.3564, which is only slightly different from the total CSR score.

The results of the four qualitative areas of CSR performance evaluation are revealed as follows: The sample companies receive 5.8161 out of 9 scores for corporate governance (achievement rate $=65 \%$ ); 4.5454 out of 10 scores for sustainable environmental development (achievement rate $=45 \%$ ); 9.1412 out of 11 scores for social welfare maintenance (achievement rate $=83 \%$ ); and 2.015 out of 8 scores for CSR information disclosure enhancement (achievement rate $=25 \%$ ). Based on these results, companies listed in TSE require investments in their sustainable environmental development and CSR information disclosure. The values for firm capabilities range between 0 and 1 , and the mean is 0.7035 , which is 0.2965 lower than the value of the company that showed the most optimal firm capabilities. This suggests that the companies listed in TSE are substantially different in terms of their firm capabilities.

\subsection{Empirical analysis of CSR and credit ratings}

Table 2 presents the empirical results. The coefficients of CSR are not related to credit ratings (except for CSR_SE). However, the coefficients of CAP have a significantly negative influence on credit ratings (except for $C S R_{-} S C$ ), implying that firms with high firm capabilities have higher credit ratings. The coefficients of $C S R \times C A P$ further demonstrate a significantly negative relationship with credit ratings.

Our evidence does not support that CSR activities can increase a firm's credit rating. Firm capabilities, however, can improve credit ratings, and the relationship between CSR and credit ratings is significant for firms with high capability. This implies that the role of CSR in credit ratings can benefit only firms with high capability.

Table 2 reports that several control variables (e.g., DY, MD, CUMERT, TV, LNSIZE, LNAGE, and $C F V$ ) are significantly related to credit ratings.

\subsection{Robustness check}

To investigate the relationship between CSR and credit ratings conditional on firm capability, we re-perform our regression analysis after partitioning the sample based on the median values of the firm capability and report the results in Table 3. We find significantly negative coefficients on CSR when firms have high capability (expect for CSR_ID). However, when firms have low capability, the relationship between CSR and credit ratings is insignificant. The results confirm that CSR activities are beneficial to credit ratings only for firms with high capabilities, and this corresponds with the results in Table 2 . We find that firm capability is significantly and negatively associated with credit ratings for both firms with high and low capability, consistent with the results in Table 2.

\section{Conclusion}

This study reexamines the effects of CSR on credit ratings. Our results show that CSR activities are not associated with higher credit ratings, inconsistent with previous results (Attig et al., 2013; Jiraporn et al., 2014). However, we find that firm capability is significantly related to credit ratings, and CSR activities positively affect credit ratings for firms with high capability.

Our evidence supports that companies must achieve a certain level of firm capabilities before they can generate insurance-like assets through participation in CSR activities (Luo and Bhattacharya, 2006; Krasnikov and Jayachandran, 2008). This study offers managers a new perspective that CSR is a factor complementary to firm capabilities. Firms should improve their capabilities (such as international orientation, marketing capabilities, sales capabilities, operations capabilities, financial resources, and R\&D capabilities) to enhance corporate financial performance and the benefits of CSR, which in turn leads to better credit ratings. 


\section{References}

Assaf, A.G., and Magnini, V. (2012) Accounting for customer satisfaction in measuring hotel efficiency: evidence from the US hotel industry. International Journal of Hospitality Management, 31(3), 642647.

Attig, N., Ghoul, S.E., Guedhami, O., and Suh, J. (2013) Corporate Social Responsibility and Credit Ratings. Journal of Business Ethics, 117, 679-694.

Ayabakan, S., Bardhan, I.R., and Zheng, Z. (2017) A data envelopment analysis approach to estimate IT-enabled production capability. MIS Quarterly, 41(1), 189-205.

Bakshi, G., Madan, D., and Zhang, F.X. (2006) Investigating the role of systematic and firm-specific factors in default risk: Lessons from empirically evaluating credit risk models. Journal of Business, 79(4), 1955-1987.

Hsu, F.J., and Liu, I.C. (2017) Quantitative easing and default probability of corporate social responsibility in US. Applied Economics Letters, 24(10), 681-385.

Jiraporn, P., Jiraporn, N., Boeprasert, A., and Chang, K. (2014) Does Corporate Social Responsibility (CSR) Improve Credit Ratings? Evidence from Geographic Identification. Financial Management, 43(3), 505-531.

Keats, B.W., and Hitt, M.A. (1988) A causal model of linkages among environmental dimensions, macro-organizational characteristics and performance. Academy of Management Journal, 31(3), 570-598.

Kim, Y., Li, H., and Li, S. (2014) Corporate social responsibility and stock price crash risk. Journal of Banking \& Finance, 43(1), 1-13.

Kothari, S.P., Leone, A.J., and Wasley, C.E. (2005) Performance matched discretionary accrual measures. Journal of Accounting and Economics, 39, 163-197.

Krasnikov, A., and Jayachandran, S. (2008) The relative impact of marketing, research-and-development, and operations capabilities on firm performance. Journal of Marketing, 72 (4), 1-11.

Luo, X., and Bhattacharya, C.B. (2006) Corporate social responsibility, customer satisfaction, and market value. Journal of Marketing, 70(4), 1-18.

Santhanam, R., and Hartono, E. (2003) Issues in linking information technology capabilities to firm performance, MIS Quarterly, 27(1), 125-153.

Shahrour, M.H., Girerd-Potin, I., and Taramasco, O. (2021), Corporate social responsibility and firm default risk in the Eurozone: a market-based approach, Managerial Finance, Vol. ahead-of-print No. ahead-of-print. https://doi.org/10.1108/MF-02-2020-0063

Sun, W., and Cui, W. (2014) Linking corporate social responsibility to firm default risk. European Management Journal, 32, 275-287.

Teece, D.J., Pisano, G., and Shuen, A. (1997) Dynamic capabilities and strategic management. Strategic Management Journal, 18(7), 509-533.

Vassalou, M., and Xing, Y. (2004) Default risk in equity returns. The Journal of Finance, 59(2), 831-868. 


\section{Appendix}

Table 1: Descriptive statistics

\begin{tabular}{|c|c|c|c|c|c|c|}
\hline Variables & Mean & S.D. & Median & Highest & Lowest & Sum \\
\hline \multicolumn{7}{|c|}{ Credit rating indicator } \\
\hline RATING & 5.4202 & 1.6435 & 5.0000 & 10.0000 & 1.0000 & 2061 \\
\hline \multicolumn{7}{|l|}{ CSR variables } \\
\hline CSR_TOTAL & 21.5177 & 5.1780 & 21.0000 & 35.0000 & 8.0000 & 2061 \\
\hline$C S R \_N E G$ & 21.3564 & 5.0846 & 21.0000 & 35.0000 & 7.0000 & 2061 \\
\hline$C S R \_G V$ & 5.8161 & 1.7719 & 6.0000 & 9.0000 & 1.0000 & 2061 \\
\hline$C S R \_S E$ & 4.5454 & 1.9460 & 4.0000 & 9.0000 & 0.0000 & 2061 \\
\hline CSR_SC & 9.1412 & 1.3278 & 9.0000 & 11.0000 & 4.0000 & 2061 \\
\hline CSR_ID & 2.0150 & 1.6308 & 1.0000 & 8.0000 & 0.0000 & 2061 \\
\hline \multicolumn{7}{|l|}{ Firm capabilities } \\
\hline CAP & 0.7035 & 0.2006 & 0.7210 & 1.0000 & 0.0010 & 2061 \\
\hline \multicolumn{7}{|c|}{ Control variables } \\
\hline \multicolumn{7}{|c|}{ Environmental uncertainty } \\
\hline$D Y$ & 1.0173 & 0.0113 & 1.0151 & 1.0538 & 1.0054 & 2061 \\
\hline$C M$ & 0.8500 & 0.1204 & 0.9063 & 0.9510 & 0.1234 & 2061 \\
\hline \multicolumn{7}{|c|}{ Managers' discretionary power to disclose information } \\
\hline$M D$ & 0.0012 & 0.1339 & -0.0011 & 3.9262 & -1.3321 & 2061 \\
\hline \multicolumn{7}{|c|}{ Characteristic of stock price fluctuation } \\
\hline LEV & 0.4263 & 0.1818 & 0.4309 & 0.9782 & 0.0114 & 2061 \\
\hline CUMRET & 8.5315 & 32.9116 & 4.7122 & 256.3615 & -95.1144 & 2061 \\
\hline$T V$ & 0.4322 & 0.8995 & 0.1662 & 14.6033 & 0.0000 & 2061 \\
\hline \multicolumn{7}{|c|}{ Other control variables } \\
\hline$R O A$ & 8.4520 & 12.1938 & 7.8600 & 96.4500 & -377.8200 & 2061 \\
\hline LNSIZE & 15.6767 & 1.4177 & 15.5549 & 22.0338 & 11.7095 & 2061 \\
\hline$L N A G E$ & 3.4469 & 0.4196 & 3.4965 & 4.2341 & 1.9459 & 2061 \\
\hline$C F V$ & 0.0263 & 0.0359 & 0.0187 & 1.1347 & 0.0003 & 2061 \\
\hline$C F G$ & -1.5268 & 51.1353 & -1.0922 & 1028.6800 & -1610.4400 & 2061 \\
\hline
\end{tabular}


Table 2: Empirical results on the effect of CSR on credit ratings

\begin{tabular}{|c|c|c|c|c|c|c|}
\hline \multirow{2}{*}{$\begin{array}{c}\text { Explanatory variables } \\
\text { (expected relationship) }\end{array}$} & \multicolumn{6}{|c|}{ Dependent variable: $R A T I N G$} \\
\hline & $(1)$ & $(2)$ & (3) & $(4)$ & $(5)$ & $(6)$ \\
\hline \multicolumn{7}{|l|}{ CSR variables } \\
\hline \multirow[t]{2}{*}{$\operatorname{CSR}(-)$} & CSR_TOTAL & $C S R \_N E G$ & $C S R \_G V$ & CSR_SE & $C S R \_S C$ & $C S R \_I D$ \\
\hline & 0.0265 & 0.0227 & -0.1004 & $0.3175 * * *$ & 0.0372 & 0.0268 \\
\hline \multicolumn{7}{|l|}{ Firm capabilities } \\
\hline$C A P(-)$ & $-2.5656 * * *$ & $-2.4532 * *$ & $-4.1885^{* * *}$ & $-2.1153 * * *$ & -1.9302 & $-4.0944 * * *$ \\
\hline \multicolumn{7}{|c|}{ Moderation effect of firm capabilities } \\
\hline$C S R \times C A P(-)$ & $-0.0763 *$ & $-0.0824 *$ & 0.0134 & $-0.4822 * * *$ & -0.2498 & -0.0166 \\
\hline \multicolumn{7}{|l|}{ Control variables } \\
\hline \multicolumn{7}{|l|}{ Environmental uncertainty } \\
\hline$D Y(+)$ & $15.6210^{* *}$ & $15.8366^{* *}$ & $15.0639 * *$ & $15.7417 * *$ & $14.7952 * *$ & $14.5513 *$ \\
\hline$C M(+)$ & 1.4345 & 1.5415 & 0.2913 & 2.0193 & 0.2393 & 1.1489 \\
\hline \multicolumn{7}{|c|}{ Managers' discretionary power to disclose information } \\
\hline$M D(+)$ & $0.8091 * * *$ & $0.8055 * * *$ & $0.8024 * * *$ & $0.8371 * * *$ & $0.7750 * * *$ & $0.8286^{* * *}$ \\
\hline \multicolumn{7}{|c|}{ Characteristic of stock price fluctuation } \\
\hline$L E V(+)$ & 0.3795 & 0.3787 & $0.4054 *$ & 0.3551 & 0.3764 & $0.3972 *$ \\
\hline $\operatorname{CUMRET}(+)$ & $0.0045^{* * *}$ & $0.0044 * * *$ & $0.0044 * * *$ & $0.0047 * * *$ & $0.0046 * * *$ & $0.0046 * * *$ \\
\hline$T V(+)$ & $0.1389 * * *$ & $0.1397 * * *$ & $0.1440 * * *$ & $0.1354 * * *$ & $0.1394 * * *$ & $0.1365 * * *$ \\
\hline \multicolumn{7}{|l|}{ Other control variables } \\
\hline$R O A(-)$ & -0.0019 & -0.0021 & -0.0015 & -0.0015 & -0.0018 & -0.0012 \\
\hline LNSIZE (-) & $-1.6248 * * *$ & $-1.6168 * * *$ & $-1.6372 * * *$ & $-1.6640 * * *$ & $-1.6332 * * *$ & $-1.6741 * * *$ \\
\hline$L N A G E(-)$ & $-0.3054 * *$ & $-0.3034 * *$ & $-0.2991 * *$ & $-0.3119 * *$ & $-0.3282 * * *$ & $-0.3233 * * *$ \\
\hline$C F V(+)$ & $-3.9469 * * *$ & $-3.9686 * * *$ & $-3.9049 * *$ & $-3.6998 * *$ & $-3.9084 * *$ & $-3.9167 * *$ \\
\hline$C F G(+)$ & 0.0007 & 0.0006 & 0.0007 & 0.0007 & 0.0007 & 0.0007 \\
\hline DUMMY_IND & Yes & Yes & Yes & Yes & Yes & Yes \\
\hline$D U M M Y \_Y E A R$ & Yes & Yes & Yes & Yes & Yes & Yes \\
\hline Observed sample size & 2061 & 2061 & 2061 & 2061 & 2061 & 2061 \\
\hline
\end{tabular}

Note: $* * *$ indicates significance at the $1 \%$. ** indicates significance at the $5 \%$. indicates significance at the $10 \%$. 
Table 3: Subsample analysis on the effect of CSR on credit ratings

\begin{tabular}{|c|c|c|c|c|c|c|c|c|c|c|c|c|}
\hline \multirow{3}{*}{$\begin{array}{l}\text { Explanatory variables } \\
\text { (expected relationship) }\end{array}$} & \multicolumn{12}{|c|}{ Dependent variable: $R A T I N G$} \\
\hline & \multicolumn{2}{|c|}{ (1) } & \multicolumn{2}{|c|}{$(2)$} & \multicolumn{2}{|c|}{ (3) } & \multicolumn{2}{|c|}{ (4) } & \multicolumn{2}{|c|}{ (5) } & \multicolumn{2}{|c|}{ (6) } \\
\hline & $\begin{array}{l}\text { High firm } \\
\text { capabilities }\end{array}$ & $\begin{array}{c}\text { Low firm } \\
\text { capabilities }\end{array}$ & $\begin{array}{l}\text { High firm } \\
\text { capabilities }\end{array}$ & $\begin{array}{c}\text { Low firm } \\
\text { capabilities }\end{array}$ & $\begin{array}{c}\text { High firm } \\
\text { capabilities }\end{array}$ & $\begin{array}{c}\text { Low firm } \\
\text { capabilities }\end{array}$ & $\begin{array}{l}\text { High firm } \\
\text { capabilities }\end{array}$ & $\begin{array}{c}\text { Low firm } \\
\text { capabilities }\end{array}$ & $\begin{array}{c}\text { High firm } \\
\text { capabilities }\end{array}$ & $\begin{array}{c}\text { Low firm } \\
\text { capabilities }\end{array}$ & $\begin{array}{c}\text { High firm } \\
\text { capabilities }\end{array}$ & $\begin{array}{c}\text { Low firm } \\
\text { capabilities }\end{array}$ \\
\hline \multicolumn{13}{|l|}{ CSR variables } \\
\hline \multirow[t]{2}{*}{$\operatorname{CSR}(-)$} & \multicolumn{2}{|c|}{ CSR_TOTAL } & \multicolumn{2}{|c|}{$C S R \_N E G$} & \multicolumn{2}{|c|}{$C S R \_G V$} & \multicolumn{2}{|c|}{$C S R \_S E$} & \multicolumn{2}{|c|}{$C S R \_S C$} & \multicolumn{2}{|c|}{$C S R \_I D$} \\
\hline & $-0.0475^{* * *}$ & 0.0049 & $-0.0566^{* * *}$ & -0.0026 & $-0.1088^{* * *}$ & -0.0586 & $-0.0938^{* * * *}$ & $0.0785 * *$ & $-0.1954 * * *$ & -0.0619 & -0.0312 & 0.0704 \\
\hline \multicolumn{13}{|l|}{ Firm capabilities } \\
\hline$C A P(-)$ & $-4.8677^{* * *}$ & $-4.2253^{* * *}$ & $-4.8663^{* * *}$ & $-4.2142 * * *$ & $-4.8011 * * *$ & $-4.2122 * * *$ & $-4.8355^{* * *}$ & $-4.2042 * * *$ & $-5.0018 * * *$ & $-4.1595 * * *$ & $-4.8078 * * *$ & $-4.2868 * * *$ \\
\hline \multicolumn{13}{|l|}{ Control variables } \\
\hline \multicolumn{13}{|c|}{ Environmental uncertainty } \\
\hline$D Y(+)$ & 3.4121 & $33.4423 * *$ & 3.6982 & $33.2639^{* *}$ & 3.8235 & $33.1007^{* *}$ & 2.7124 & $34.9211 * *$ & 3.1774 & $32.9555 * *$ & 2.5932 & $32.5738 * *$ \\
\hline$C M(+)$ & -8.4828 & 13.2665 & -8.1994 & 13.1704 & -9.1282 & 11.8622 & -8.6927 & 11.7888 & -9.0338 & 12.3911 & -8.8630 & 12.5968 \\
\hline \multicolumn{13}{|c|}{ Managers' discretionary power to disclose information } \\
\hline$M D(+)$ & $1.1155^{* * *}$ & -0.2257 & $1.1109^{* * *}$ & -0.2184 & $1.1154 * * *$ & -0.2260 & $1.1490 * * *$ & -0.2642 & $1.0585^{* * *}$ & -0.2036 & $1.1484 * * *$ & -0.2433 \\
\hline \multicolumn{13}{|c|}{ Characteristic of stock price fluctuation } \\
\hline$L E V(+)$ & $0.7928 * *$ & 0.0910 & $0.7975 * *$ & 0.0881 & $0.8135^{* *}$ & 0.0986 & $0.7891 * *$ & 0.1105 & $0.7760 * *$ & 0.0812 & $0.8114 * *$ & 0.1036 \\
\hline CUMRET $(+)$ & $0.0062 * * *$ & 0.0028 & $0.0062^{* * *}$ & 0.0028 & $0.0064 * * *$ & 0.0027 & $0.0063^{* * *}$ & 0.0031 & $0.0066^{* * *}$ & 0.0028 & $0.0065^{* * *}$ & 0.0031 \\
\hline$T V(+)$ & $0.2082 * *$ & $0.1005^{*}$ & $0.2076 * *$ & $0.1013^{*}$ & $0.2062 * *$ & $0.1063^{*}$ & $0.2103 * *$ & $0.0987^{*}$ & $0.2080^{* *}$ & $0.1013^{*}$ & $0.1995^{* *}$ & $0.1028 *$ \\
\hline \multicolumn{13}{|l|}{ Other control variables } \\
\hline$R O A(-)$ & 0.0050 & -0.0037 & 0.0046 & -0.0038 & 0.0066 & -0.0039 & 0.0052 & -0.0031 & 0.0050 & -0.0039 & 0.0059 & -0.0035 \\
\hline LNSIZE (-) & $-1.7383^{* * *}$ & $-1.5598^{* * * *}$ & $-1.7343^{* * *}$ & $-1.5470^{* * *}$ & $-1.7767 * * *$ & $-1.5312 * * *$ & $-1.7666^{* * *}$ & $-1.6016^{* * *}$ & $-1.7657 * * *$ & $-1.5350 * * *$ & $-1.7955^{* * *}$ & $-1.6006^{* * *}$ \\
\hline$L N A G E(-)$ & -0.1272 & $-0.4288 * * *$ & -0.1236 & $-0.4237 * * *$ & -0.1465 & $-0.4094^{* *}$ & -0.1312 & $-0.4423 * * *$ & -0.1698 & $-0.4328 * * *$ & -0.1519 & $-0.4634 * * *$ \\
\hline$C F V(+)$ & -4.6244 & $-4.1842 * * *$ & -4.6023 & $-4.2097 * * *$ & -4.6811 & $-4.1546^{* *}$ & -4.8816 & $-4.0129 * *$ & -4.3054 & $-4.2553 * * *$ & -4.6454 & $-4.1078^{* *}$ \\
\hline$C F G(+)$ & 0.0011 & 0.0005 & 0.0010 & 0.0004 & 0.0011 & 0.0004 & 0.0009 & 0.0006 & 0.0011 & 0.0004 & 0.0009 & 0.0007 \\
\hline$D U M M Y \_I N D$ & \multicolumn{2}{|c|}{ Yes } & \multicolumn{2}{|c|}{ Yes } & \multicolumn{2}{|c|}{ Yes } & \multicolumn{2}{|c|}{ Yes } & \multicolumn{2}{|c|}{ Yes } & \multicolumn{2}{|c|}{ Yes } \\
\hline DUMMY_YEAR & \multicolumn{2}{|c|}{ Yes } & & & & & & & & & & \\
\hline Observed sample size & 1107 & 954 & 1107 & 954 & 1107 & 954 & 1107 & 954 & 1107 & 954 & 1107 & 954 \\
\hline
\end{tabular}

Note: $* * *$ indicates significance at the $1 \%$. $* *$ indicates significance at the $5 \%$. $*$ indicates significance at the $10 \%$. 